\title{
Indoor Air Quality Related to Occupancy at an Air- conditioned Public Building
}

\author{
Karina Ponsoni and Maria Stella Gonçalves Raddi* \\ Faculdade de Ciências Farmacêuticas de Araraquara; Universidade Estadual Paulista; Rua Expedicionários do \\ Brasil, 1621; C. P. 503; 14801-902; Araraquara-SP - Brasil
}

\begin{abstract}
To characterize the influence of occupancy on the indoor air quality, a public office building with air-conditioning system was selected for this study. The indoor parameters included total bacteria count, total fungal count, temperature, relative humidity, and carbon dioxide concentration. The number of occupants, which varied throughout the day, was recorded in each sample. The samples were taken before the beginning of the working day and during $3 \mathrm{~h}$, at an interval of $30 \mathrm{~min}$ between each sampling, and continued for five working days during a week. Correlation analysis demonstrated that occupancy rates were positively correlated with airborne bacteria, $\mathrm{CO}_{2}$, and temperature. No significant association between the number of occupants and fungus was observed. The results of this study provided information on the variability of indoor air parameters during the time-varying occupancy over the course of the day in at air-conditioned buildings where occupancy was quite dynamic.
\end{abstract}

Key words: Indoor air quality, air-conditioned, occupancy, office building

\section{INTRODUCTION}

The last decade has been characterized by a significant increase of worldwide scientific database in indoor environments. People recognize that indoor air quality may be more important than outdoor air quality because they spend over $70 \%$ of their time indoors (Guo et al., 2004). Applications of heating, ventilation and airconditioning system is known to modify the indoor air quality by means of filtration, humidification, dilution and cooling the outdoor air entering the occupied space. For instances, adequate filtration of outdoor air intake of air-conditioning system through a well-maintained filter can be effective in preventing outdoor microbial contamination associated with outdoor sources of environmental microbes in air-conditioning buildings (Wu et al.,
2005). Air-conditioning system has also been shown to contribute to the rising fungal contamination in indoor air from various components in the system (Ahearn et al., 1997).

The indoor $\mathrm{CO}_{2}$ level is one commonly used approach which has been referred as an indoor air quality indicator (Lin \& Deng, 2003). The acceptability of using measured space $\mathrm{CO}_{2}$ concentrations to correlate acceptable indoor air quality has been controversial (ASHRAE Standard $62,2001)$. It is known that ventilation is necessary to remove the indoor-generated pollutants from indoor air or dilute their concentration to acceptable levels (Seppanen \& Fisk, 2004). Successful operation of ventilation systems has long been considered a critical variable affecting the indoor microbial contamination. However, a great number of occupants themselves influence

\footnotetext{
* Author for correspondence: raddims@fcfar.unesp.br
} 
the air quality. Despite of the intense interest on indoor air quality some of the parameters that contribute to the pollution of indoor environments are not well understood.

The overall objective of the study was to examine the influence of occupant density on the indoor air parameters in a large office building with mechanical ventilation system.

\section{MATERIALS AND METHODS}

\section{Survey protocol}

A public office building equipped with central station air-handling equipment without humidity system was selected. The samples were conducted before the beginning of the working day and during $3 \mathrm{~h}$, at an interval of $30 \mathrm{~min}$ between each sampling. The number of occupants, which varied throughout the day, was recorded in each sample. The measurements were conducted everyday and continued for five working days during a week.

\section{Microbiological analyses}

Indoor air samples $(200 \mathrm{~L})$ were collected in the center of the room approximately $1.5 \mathrm{~m}$ above floor level using a single-stage sampler (MAS100, MERCK). Trypticase Soy Agar (TSA) (Acumedia) with $0.5 \mathrm{~g} / \mathrm{L}$ cycloheximide (Sigma) and Sabouraud Dextrose Agar w/Chloramphenicol (Acumedia) were used for total bacteria and fungi, respectively. Cultures on TSA were incubated at
$35 \pm 2^{\circ} \mathrm{C}$ for $48 \mathrm{~h}$, while agar sabourand plates were incubated at room temperature for $5 \mathrm{~d}$ prior to counting. After applying the positive hole correction procedure recommended by MERCK, the results were expressed in colony forming unit per cubic meter $\left(\mathrm{CFU} / \mathrm{m}^{3}\right)$.

\section{Other parameters}

Temperature and relative humidity were recorded simultaneously with a portable digital anemometer (NK 3000, Kestrel, England) and $\mathrm{CO}_{2}$ was measured using the monitor TESTO 535 (BSRIA Instrument Solution, England).

\section{Data analyses}

All independent, continuous variables were tested for linear correlation to each other (Person r).

\section{RESULTS}

Since the main interest of this study was to investigate how the indoor parameters would vary as function of occupancy, the graphics presented in Figure $1(\mathrm{~A}-\mathrm{F})$ allowed a detailed analysis of the results distribution. Correlation analysis was conduct between the occupancy and indoor environment parameters inside the air-conditioned building. The results of the coefficients are shown in Table 1. Table 2 summarizes the concentrations of the indoor parameters environmental variables.

Table 1 - Correlation between indoor concentrations of total bacteria $\left(\mathrm{CFU} / \mathrm{m}^{3}\right)$, total fungi $\left(\mathrm{CFU} / \mathrm{m}^{3}\right), \mathrm{CO}_{2}(\mathrm{ppm})$, relative humidity $(\%)$, temperature $\left({ }^{\circ} \mathrm{C}\right)$, particle mass $\left(\mu \mathrm{g} / \mathrm{m}^{3}\right)$, and occupancy (person) inside the air-conditioned building

\begin{tabular}{lccccccc}
\hline & $\begin{array}{c}\text { Total } \\
\text { bacteria }\end{array}$ & $\begin{array}{c}\text { Total } \\
\text { fungi }\end{array}$ & $\mathrm{CO}_{2}$ & $\begin{array}{c}\text { Relative } \\
\text { humidity }\end{array}$ & Temperature & $\begin{array}{c}\text { Particle } \\
\text { mass }\end{array}$ & Occupancy \\
\hline Total bacteria & 1.00 & & & & & & \\
Total Fungi & 0.06 & 1.00 & & & & & \\
$\mathrm{CO}_{2}$ & 0.12 & -0.35 & 1.00 & & & & \\
Relative humidity & -0.24 & -0.07 & 0.06 & 1.00 & & & \\
Temperature & $0.43^{*}$ & 0.14 & -0.12 & $-0.49^{*}$ & 1.00 & & \\
Particle mass & $0.53^{*}$ & $0.55^{*}$ & 0.37 & $0.56^{*}$ & $-0.55^{*}$ & 1.00 & \\
Occupancy & $0.58^{*}$ & -0.08 & $0.58^{*}$ & -0.38 & $0.49^{*}$ & 0.32 & 1.00 \\
\hline *
\end{tabular}


Table 2 - Distribution of environmental variables

\begin{tabular}{lcccc}
\hline Environmental variables & Mean \pm SD & Median & Minimum & Maximum \\
\hline Total bacteria $\left(\mathrm{CFU} / \mathrm{m}^{3}\right)$ & $541 \pm 395$ & 415 & 110 & 1955 \\
Total fungi $\left(\mathrm{CFU} / \mathrm{m}^{3}\right)$ & $2863 \pm 497$ & 2870 & 989 & 5256 \\
$\mathrm{CO}_{2}(\mathrm{ppm})$ & $612 \pm 136$ & 609 & 386 & 1050 \\
Relative humidity $(\%)$ & $44 \pm 4$ & 44 & 37 & 50 \\
Temperature $\left({ }^{\circ} \mathrm{C}\right)$ & $26.3 \pm 1.2$ & 26.3 & 22.5 & 28.1 \\
Particle mass $\left(\mu \mathrm{g} / \mathrm{m}^{3}\right)$ & $117,3 \pm 90,7$ & 100 & 0 & 270 \\
\hline
\end{tabular}

A

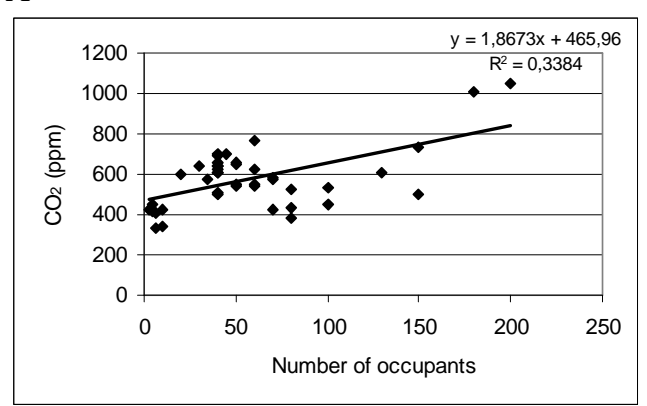

$\mathrm{C}$

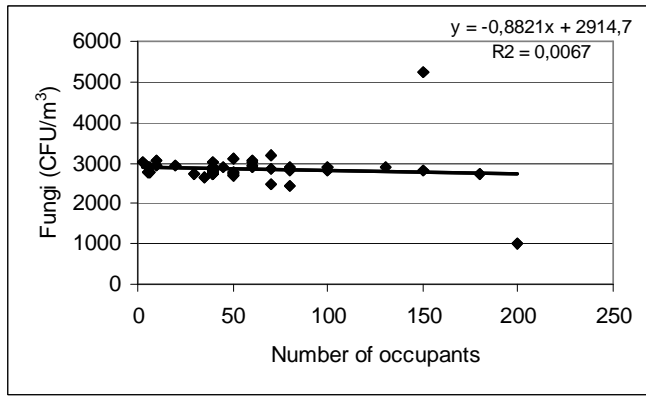

$\mathrm{E}$

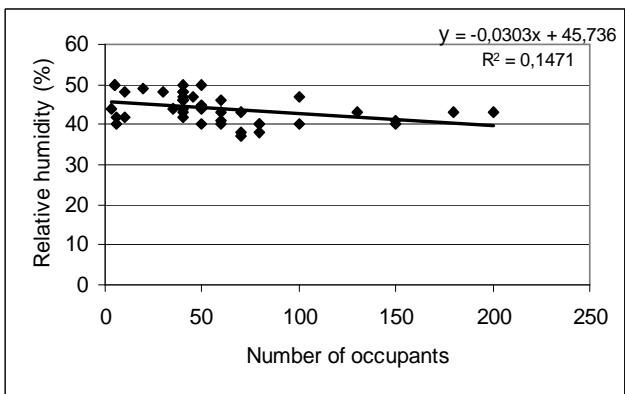

B

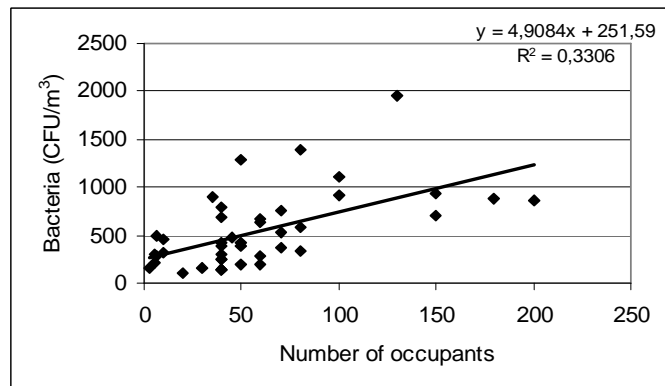

$\mathrm{D}$

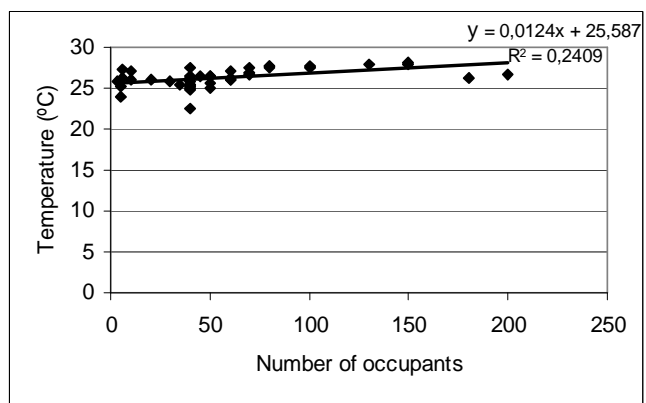

$\mathrm{F}$

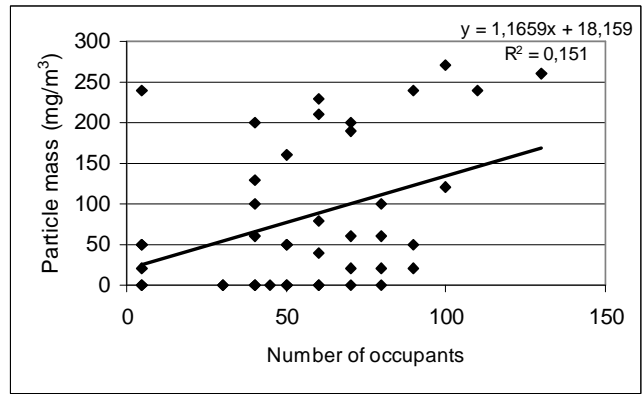

Figure 1 - Occupation and indoor environment parameters inside the air-conditioned building: (A) $\mathrm{CO}_{2}(\mathrm{ppm}) ;(\mathrm{B})$ Bacteria $\left(\mathrm{CFU} / \mathrm{m}^{3}\right) ;(\mathrm{C})$ Fungi $\left(\mathrm{CFU} / \mathrm{m}^{3}\right) ;(\mathrm{D})$ Temperature $\left({ }^{\circ} \mathrm{C}\right) ;(\mathrm{E})$ Relative humidity (\%); Particle mass $\left(\mathrm{mg} / \mathrm{m}^{3}\right)(\mathrm{F})$. 


\section{DISCUSSION}

Characterization of environmental air contaminants in a space when it is unoccupied impedes a critical evaluation of indoors air quality for the time-varying occupancy over the course of the day in at air-conditioned buildings where occupancy is quite dynamic. Occupants themselves contribute bioeffluent emissions to the air, which include volatile organic compounds, water vapor, particulate matter, $\mathrm{CO}_{2}$ and bioaerosols (Engvall et al., 2005). A consistent relationship between the occupancy and corresponding carbon dioxide concentrations was seen in the present study. In two instances, $\mathrm{CO}_{2}$ level exceeded $1000 \mathrm{ppm}$.

This implied that the operation of air-conditioning did not significantly reduce the levels of these air pollutant in the building. Health authorities do not generally consider $\mathrm{CO}_{2}$ at typical indoor concentrations as a health hazard. The $1000 \mathrm{ppm}$ indoor concentration or the $700 \mathrm{ppm}$ difference between the indoor and outdoor $\mathrm{CO}_{2}$ concentration limit specified in the ASHRAE Standard 62 (2001) is based on its association with human body odor, not with any health or comfort effects of $\mathrm{CO}_{2}$ itself. Although, the concentrations below 1000 ppm do not always guarantee that ventilation rate is adequate for removal of air pollutants from other indoor sources (Apte et al., 2000). Adequate $\mathrm{CO}_{2}$ control in a room is possible by limiting the number of occupants or increasing the sources of fresh air in the room.

Epithelial and mucosal surfaces are colonized with bacteria, microflora that become liberated through the normal shedding of skin cells or though aerosolization from mucosal surfaces by talking, coughing or sneezing. High concentration of bacteria contributed by room occupants influenced the air quality independent of an infectious disease (Bartlett et al., 2004). The geometric mean indoor concentration of airborne bacterial was 541 $\mathrm{CFU} / \mathrm{m}^{3}$ ranging from 110 to $1955 \mathrm{CFU} / \mathrm{m}^{3}$.

Presently, there is no sufficient information on dose-exposition relationships regarding viable and cultivable biological agents (Dacarro et al., 2003). Despite the intense interest in the role of bioaerosols to health, there is no consensus for regulatory limits on airborne bacterial concentrations in indoor air (Bartlett et al., 2004). A significant correlation between occupant density and indoor bacteria concentration support the future application of using bacteria levels as an indicator for indoor-originated contamination.

For fungus, although an elevated indoor concentration was observed it was not found related to a greater number of occupants. These data were in agreement with the fact that the most probably source of air contamination by these microorganisms were indoor sources (Roos et al., 2004). Actually, the reference value for fungus is limited to $750 \mathrm{CFU} / \mathrm{m}^{3}$, suggesting that higher values must have a fungi source that should be investigated (Rao et al., 1996). The currant data was able to demonstrate that the fungal concentrations could be associated with indoor source of contamination other than human origin.

The effect of air temperature on thermal comfort is well known, but its effect on air quality is not widely recognized (Seppänen \& Fisk, 2004). This study also demonstrated that occupancy in airconditioned indoor environment had impact in the temperature. This information could be used as a parameter of excess of occupants $/ \mathrm{m}^{3}$.

The pollution of indoor environments has achieved great importance first and foremost by the increasing number of officially reported cases involving people with health problems related to their professional environment, reduce productivity and increase absence (Wyon, 2004). Public buildings are representative of a variety of building styles, ages, and construction materials. Many office building were built before forced air ventilation became a routine feature, and there is a need to provide a baseline for what is considered to be acceptable for these environments.

Adequate air change is necessary in airconditioned buildings for diluting many air pollutants of indoor origin. It is known that ventilation is necessary to remove the indoorgenerated pollutants to acceptable values. But as the limit values of all indoor pollutants are not known, the exact determination of required ventilation rates based on pollutants concentrations and associated risk is seldom possible (Seppänen $\&$ Fisk, 2004). The effects of ventilation on indoors air quality and health is a complex issue. Most of the existing literature indicates that increasing ventilation rate will be an effective way to improve indoor air quality; however, in most cases, it results in the consumption of more energy (Lin \& Deng, 2003). A limitation of the present study was that the ventilation rate could not be collected. 
In conclusion, although more studies would be needed to determine the extent of occupancy in indoors parameters, its clear that many offices would not be able to comport a high number of occupants maintaining a good air quality. Evidences showed that ventilation was necessary to assure the adequate dilution of contaminants generated in the occupied space. Ventilation systems for spaces with variable occupancy may provide sufficient dilution to maintain contaminant concentrations within acceptable levels at all time.

\section{ACKNOWLEDGMENTS}

FAPESP AND FUNDUNESP supported this work. We thank Prof. Romeu Magnani for help with statistics

\section{RESUMO}

Com o objetivo de caracterizar a influência da ocupação na qualidade do ar interior, um edifício público com sistema de ar condicionado foi selecionado. As variáveis ambientais consideradas incluíram contagem total de bactérias e fungos, temperatura, umidade relativa e concentração de dióxido de carbono. O número de ocupantes, que variou durante todo o dia, foi estimado em cada amostragem. As amostras foram coletadas antes do início do expediente de trabalho e durante 3 horas, em intervalos de 30 minutos, por 5 dias úteis consecutivos. A análise de correlação demonstrou que a taxa de ocupação foi correlacionada positivamente com a concentração de bactérias, dióxido de carbono e temperatura. Nenhuma associação significativa foi observada entre o número de ocupantes e concentração de fungos. Os resultados deste estudo fornecem informações quanto à variabilidade nos parâmetros do ar interior no decorrer do dia em um edifício onde a ocupação é dinâmica.

\section{REFERENCES}

Ahearn, D.G.; Crow, S.A.; Simmons, R.B.,; Price, D.L.; Mishra, S.K. and Pierson, D.L.(1977), Fungal colonization of air filters and insulation in a multistory office building: Production of volatile organics. Curr. Microbiol., 35, 305-308.
Apte, M.G.; Fisk, W.J. and Daisy, J.M. (2000), Associations between indoor $\left(\mathrm{CO}_{2}\right)$ concentrations and sick building syndrome symptoms in US Office Buildings: an analysis of the 1994-1996 BASE Study Data (LBNL 44385). Indoor Air, 10, 246-257.

ASHRAE Standard 62-2001 (2001), Ventilation for acceptable indoor air quality, American Society of Heating, Refrigeration, and Air-conditioning Engineers, Atlanta, USA.

Bartlett, K.H.; Kennedy, S.M.; Brauer, M.; van Netten, C. and Dill, B. (2004), Evaluation and determinants of airborne bacterial concentrations in school classrooms. J. Occup. Environ. Hyg., 1, 639-647.

Dacarro, C.; Picco, A.M.; Grisoli, P. and Rodolfi, M. (2003), Determination of aerial microbiological contamination in scholastic sports environments. $J$. Appl. Microbiol., 95, 904-912.

Daisy, J.M.; Angell, W.J. and Apte, M.G. (2003), Indoor air quality, ventilation and health symptoms in schools: an analysis of existing information. Indoor Air, 13, 53-64.

Engvall, K.; Wickman, P. and Norack, D. (2005) Sisk building syndrome and perceived indoor environment in relation to energy saving by reduced ventilation flow during heating season: a 1 year intervention study in dwellings. Indoor Air, 15, 120-126.

Guo, H.; Lee, S.C. and Chan, L.Y. (2004), Indoor air quality investigation at air-conditioned and non-airconditioned markets in Hong Kong. Sci. Total Environ., 323, 87-98.

Lin, Z. \& Deng, S. (2003), The outdoor air ventilation rate in high-rise residences employing room air conditioners. Build. Environ., 38, 1389-1399.

Rao, C. Y.; Burge, H. A., and Chang, J. C. S. (1996), Review of quantitative standards and guidelines for fungi in indoor air. J. Air \& Waste Manage. Assoc., 46, 899-908.

Roos, C.; Menezes, J. R.; Svidzinski, T. I. E.; Albino, U. and Andrade, G. (2004), Studies on fungal and bacterial population of air-conditioned environments. Braz. Arch. Biol. Technol., 47, 827-835.

Seppänen, O.A. \& Fisk, W.J. (2004), Summary of human responses to ventilation. Indoor Air, 14 (Suppl 7), 102-118.

Wu, P.C.; Li, Y.Y.; Chiang, C.M.; Huang, C.Y.; Lee, C.C.; Li, F.C. and Su, H.J. (2005), Changing microbial concentrations are associated with ventilation performance in Taiwan's air-conditioned office buildings. Indoor Air, 15, 19-26.

Wyon, D.P. (2004), The effects of indoor air quality on performance and productivity. Indoor Air, 14, 92101. 